\title{
Public Policies on Innovation and Small Businesses in a Swinging Economy
}

Glessia Silva ${ }^{1,2}$

Luiz Carlos Di Serio ${ }^{2}$ Éder Danilo Bezerra ${ }^{2}$

${ }^{1}$ Universidade Federal de Sergipe, São Cristóvão, SE, Brazil

${ }^{2}$ Fundação Getulio Vargas, São Paulo, SP, Brazil

Received 27 November 2018. This paper was with the authors for three revisions. Accepted 5 July 2019. First published online 5 August 2019.

Thiago Ferreira Dias was the associate editor for this article.

Editorial assistant: Luciane Kato Kiwara

Editor-in-chief: Carlo Gabriel Porto Bellini 


\section{Abstract}

The purpose of this paper is to analyze the adequacy of public policies that support innovation in small businesses in a swinging economy, particularly in Brazil. ${ }^{1}$ In order to make our case for more adequate public policies on innovation, we develop five propositions based on the assumption that innovation policies focused on fostering socioeconomic development should meet. We adopted a documentary research design, as we examined the policies produced by governmental bodies and agencies at the three governmental levels in Brazil - federation, states, and cities. Also, qualitative content analysis was performed in order to organize, codify and interpret the messages delivered by current innovation policies in the country. We found that most public policies on innovation and small businesses are short-sighted and generalist, borrowing metrics and evaluation criteria from the big enterprise context in an one-size-fits-all manner that, ultimately, cannot be applied to most small businesses and local contexts. As a contribution to theory, our five propositions could be used as starting points for future policy and administration research. On a practical level, we propose recommendations to policy-makers and offer insights on how an adequate policy affects a country's competitiveness and socioeconomic development.

Keywords: innovation; public policy; small business; adequacy; swinging economy; Brazil. 


\section{Introduction}

Even though there is consensus around the idea of what constitutes contextually adequate public policies on innovation for small businesses (Berends, Jelinek, Reymen, \& Stultiëns, 2014), both policy-makers and academics turn their attention to big, technology-based, research and development $(R \& D)$ enterprises, accepting the latter's evaluation criteria as benchmarks for innovativeness (Hervas-Oliver, Garrigos, \& Gil-Pechuan, 2011; Mrożewski \& Kratzer, 2017; Storey, 2014). Such a bias harms the small businesses, as the process of public policy formulation is concentrated on the gaps and shortcomings related to big, high-technology businesses, thus resulting in short-sighted and generalist innovation policies (Von Tunzelmann \& Acha, 2005).

This situation is controversial, because the small businesses are considered the backbone of the economy and the heart of public policy (Forsman, 2011; Parida, Oghazi, \& Cedergren, 2016). This results from the dissociation between entrepreneurship and innovation policies and the fragmentation of such research domains along the years (Audretsch \& Link, 2012; Crossan \& Apaydin, 2010; Damanpour, 2014; Ferreira, Fernandes, Alves, \& Raposo, 2015; Garcia \& Calantone, 2002; Santamaría, Nieto, \& Barge-Gil, 2009). The fields of entrepreneurship and innovation are historically linked to Schumpeter's theory of economic development, but have been evolving independently (Fagerberg, Landström, \& Martin, 2012; Landström, Åström, \& Harirchi, 2015; Landström, Harirchi, \& Åström, 2012; Landström \& Harirchi, 2018).

Different visions about innovation and entrepreneurship hamper an adequate orientation of the innovation policies by making us frame innovation and entrepreneurship as different processes, thus affecting the way the entrepreneurial activity leading to innovation is valued (Audretsch \& Link, 2012). This is worrisome because the integration of innovation, entrepreneurship and the dynamics of small businesses is a key condition to enable regional development (Audretsch, 2015; Autio, Kenney, Mustar, Siegel, \& Wright, 2014; Bhupatiraju, Nomaler, Triulzi, \& Verspagen, 2012; Sahut \& Peris-Ortiz, 2014; Squicciarini, 2017; Stephens, Partridge, \& Faggian, 2013).

Another aggravating aspect of such shortcoming is that most of the studies in the field of innovation associate innovation to technology and $R \& D$, while most of the activities leading to innovation do not necessarily depend on either (Damanpour \& Wischnevsky, 2006; Keupp, Palmié, \& Gassmann, 2012). Therefore, the trajectory of the innovation phenomenon as a research field resulted in practical and theoretical gaps, making it excluding when it comes to analyzing different contexts (Freel, 2005; Mazzarol \& Reboud, 2011). As a result, researchers looking at small businesses have an excessive focus on the high-technology sector and the success stories (Brush \& Chaganti, 1999; De Jong \& Marsili, 2006; Storey, 2014). However, most of the small enterprises belong to traditional, low-technology sectors, which do not rely on $R \& D$ in the innovation process, and about three-thirds of them have no employee other than the owner (Fadahunsi, 2012; McGuirk, Lenihan, \& Hart, 2015; Plotnikova, Romero, \& Martínez-Román, 2016; Romero \& Martínez-Román, 2012; Zaridis \& Mousiolis, 2014).

Both the political system and the academia have given an overly disproportional attention to technology and $R \& D$ in the innovative process (Freel, 2005). The bias in such context creates

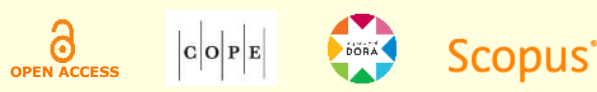


generalizations that are difficult to apply to most of the small businesses and, as a consequence, makes them marginalized in various fields of study. However, innovation at the small business level is fundamentally different from that of the big businesses, and innovation policies must consider such aspects (Acs \& Audretsch, 1988, 2010).

The failure of many public policies for the small businesses is ultimately a result of policy-makers' focus on big businesses and the academia's lack of interest in the small business (Hervas-Oliver et al., 2011; Von Tunzelmann \& Acha, 2005). Therefore, it is important that policy-makers develop public policies to encourage entrepreneurship as well as local and regional development, because an innovation policy is, by its own nature, local (Audretsch \& Link, 2012; Mirzanti, Simatupang, \& Larso, 2015; Mrożewski \& Kratzer, 2017; Roper, Love, \& Bonner, 2017). Moreover, public policies supporting innovation in small businesses must consider both the innovation context of the small enterprise itself and the local entrepreneurial context (Henrekson, 2014; Huggins \& Thompson, 2015). This is especially true in developing nations, which in general have lower innovation levels, as most of the public policies on innovation in such countries fail due to being based on the theories, policies and economic principles of developed countries (Öner \& Kunday, 2016).

Consequently, the theoretical and research body supporting the analysis of public policies on innovation does not examine the adequacy of a policy's objective as its main focus, but rather the policy's efficiency (Bajmócy \& Gébert, 2014). Even though a policy's objective is decisive for its success, most of them are formulated in a wrong manner, considering issues such as productivity, economic growth and job creations, which are typical metrics in the dominant economic theory and have little to no relation to the context they were supposed to be meant for (Bajmócy \& Gébert, 2014). To help reduce such gap, this article analyzes the adequacy of the public policies supporting innovation in small businesses in a swinging economy. We developed the following research question: Are the public policies on innovation adequate for the small businesses in Brazil?

We believe that addressing such question is important in both theoretical and practical terms. To theory, we hope to advance the discussion about the adequacy of public policies on innovation, especially in the context of small businesses; to practitioners, we present suggestions on how to improve the existing policies and creating more meaningful ones.

The article is organized as follows. First, the literature review approaches the role public policies on innovation play in the development of countries and small businesses; then we organize the discussion into five propositions derived from a literature review, which basically express five criteria on what constitutes an adequate public policy on innovation. Second, we present and discuss the methodological procedures that guided the data collection and analysis in our documentary research. Next, we present our findings and discuss implications in light of the issues raised here. Finally, we present conclusions with recommendations for future research and policy-making. 


\section{Literature Review}

An innovation policy may be conceptualized as a series of governmental activities translated into plans, programs, projects or actions aimed at fostering innovation (Audretsch \& Link, 2012; Bajmócy \& Gébert, 2014; Landström et al., 2012; Landström et al., 2015; Öner \& Kunday, 2016; Patanakul \& Pinto, 2014). Given that such policies directly affect existing businesses and have the potential of contributing to the creation of new ones, they must be integrated with the entrepreneurship policies (Bhupatiraju et al., 2012; Fagerberg, Fosaas, \& Sapprasert, 2012; Landström et al., 2015), which in turn are aimed at fostering the creation of new businesses and/or strengthening the existing ones (Borges, Bezerra, Silva, Andreassi, \& Ferreira, 2018; Lundström \& Stevenson, 2005; Minniti, 2008; Mirzanti et al., 2015; Öner \& Kunday, 2016; Qian \& Haynes, 2014). Despite the similarities, innovation and entrepreneurship policies are usually dissociated from one another in such a way that most of the current innovation policies have goals that do not reflect the context they were meant for (Audretsch \& Link, 2012; Bajmócy \& Gébert, 2014).

Public policies generally disregard the role and impact of innovation, because most policy-makers have limited knowledge on innovation and entrepreneurship (Audretsch \& Link, 2012). In addition, every public policy is formulated on the basis of economic theories carrying different and sometimes contrasting - views on how to promote the development of a country, and also the policy stance on innovation and entrepreneurship differs considerably between such economic theories (Audretsch \& Link, 2012; Costa, 2016). For example, in the classic and Keynesian economies, innovation policies are generalist ones. In classic economy, the focus lies on market efficiency in terms of production and resources allocation; and in Keynesian economy, there is an active governmental role in fiscal and monetary aspects aimed at stabilizing the economy (Audretsch \& Link, 2012; Costa, 2016). In Schumpeterian economy, on the other hand, the notion of growth and development is strongly connected to an economy based on innovation that has the entrepreneur as the principal innovative agent (Audretsch \& Link, 2012).

We argue that the Schumpeterian economic view is the most adequate for the purpose of social development and economic growth in a country. Schumpeter was responsible for taking the focus away from the classical and Keynesian economic view and, instead, focused on innovation as the foundation for change (Audretsch \& Link, 2012). His legacy lies on addressing the facts that even strong firms fail if they are not innovative, and that there are both entrepreneurs that are innovators and entrepreneurs whose main interest is to maintain the status quo (McCraw, 2007). Schumpeter has also drawn attention to the role of institutions in promoting innovation (Schumpeter, 1939). Hence, the economic view adopted by a government influences the public policies as a whole and determines the way by which innovation is valued in a country (Audretsch \& Link, 2012).

In such scenario, small businesses play an important role not only in the economic performance of a country, but also as tools to reduce social inequalities (Acs \& Szerb, 2007; Albiol-Sanchez \& Van Stel, 2016; Aldrich, 2012; J. W. Carland, Hoy, Boulton, \& Carland, 1984; Rothwell, 1989; Thurik, Stam, \& Audretsch, 2013), which in turn force governments to develop public policies

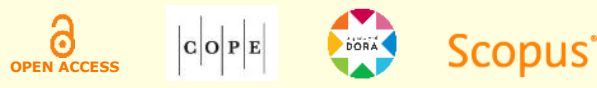


honed to the innovative context of such businesses (Bajmócy \& Gébert, 2014; Berends et al., 2014). Consequently, adequate governmental actions are important because without small businesses we would have worse jobs, lower income levels, rising unemployment and less innovation (Qian \& Haynes, 2014; Reynolds, Storey, \& Westhead, 1994; Rothwell, 1989; Storey, 2014).

This is especially true in a swinging economy. The small business has a very strong social aspect attached to it (Bruton, Ahlstrom, \& Obloj, 2008; Bygrave \& Minniti, 2000; Henrekson, 2014; Marcotte, 2014; Öner \& Kunday, 2016). Many of such companies are created by people who were marginalized by the current economic system and have therefore looked after becoming entrepreneurs as a way to improve their life styles (Barkhatov, Pletnev, \& Campa, 2016). Small businesses are also the preferred type of organization in most localities (Barkhatov et al., 2016; Gardner, 1961), because most regions have more small than big cities, and small cities are home to a constellation of small businesses providing goods and services to the local population at more competitive prices when compared to bigger companies. This reduces the chance of monopoly formation by decentralizing the economic power (Barkhatov et al., 2016).

Furthermore, small businesses are important to reduce the enormous gap between the rich and the poor as they make people more independent (Barkhatov et al., 2016). Such companies may be a strategy for poverty reduction, because the more incentives a country has to offer to small businesses the lesser the unemployment level and the higher the social welfare of the people (Autio et al., 2014; Bajmócy \& Gébert, 2014; Hadjimanolis, 1999; Stephens et al., 2013). Then, it is of great importance that policy-makers take into account the social aspect embedded to the small businesses by creating public policies on innovation which are capable of promoting social development and poverty reduction, thus allowing people to realize their aspirations and dreams (Bajmócy \& Gébert, 2014; Mirzanti et al., 2015).

Entrepreneurship and innovation are related to welfare and self-realization, which are innovation outcomes (Henrekson, 2014). Do the policies meet people's wishes? What would be the real preference of most people? Why are these preferences not explored? Public policies on innovation which explore such preferences have the potential to help fostering business opportunities in localities with little to no development perspectives (Henrekson, 2014; Huggins \& Thompson, 2015). Although governments strive to put forward small businesses in the political agenda, governmental actions hardly consider the policies' adequacy (Bajmócy \& Gébert, 2014). However, if policies are not managed well, they may have negative effects on innovation (Leitner, Wehrmeyer, \& France, 2010; Liu, Simon, Sun, \& Cao, 2011; Patanakul \& Pinto, 2014; Petrakis, Kostis, \& Valsamis, 2015).

Thus, an innovation policy aimed at fostering socioeconomic development must meet certain adequacy criteria, which are based on five fundamental aspects: it must (a) focus on local/regional development; (b) be aligned with the target audience it is aimed to reach; (c) promote the capture and assimilation of local knowledge; (d) be focused on the manager/owner; and (e) consider the innovative profile of small businesses. We now present these five criteria as propositions to

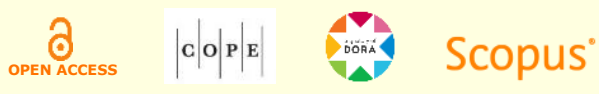


provide a better understanding on how public policies on innovation may be adequate for small businesses.

Proposition 1: Public policies on innovation must focus on local and regional development.

An innovation policy must focus on local and regional development (Audretsch \& Link, 2012; Henrekson, 2014; Mirzanti et al., 2015; Roper et al., 2017). That is because each locality has different characteristics and demands (Qian, Acs, \& Stough, 2013; Qian \& Haynes, 2014; Sahut $\&$ Peris-Ortiz, 2014; Squicciarini, 2017). Besides, the creation of a strong nation includes the process of building solid socioeconomic development of its regions, so that there are no small islands of wealth and vast pockets of poverty scattered across the land (Autio et al., 2014; Bajmócy \& Gébert, 2014; Barkhatov et al., 2016; Huggins \& Thompson, 2014, 2015; Huggins \& Williams, 2011; Stephens et al., 2013; Van Stel, Carree, \& Thurik, 2005). However, as many innovation policies are imported from developed countries, they end up being disconnected from the local and regional levels of developing and swinging economies, thus becoming inadequate to most contexts (Bajmócy \& Gébert, 2014; Barkhatov et al., 2016; Mirzanti et al., 2015; Stephens et al., 2013).

For example, as it becomes clearer that innovation policies are essential for the development of less developed countries, governments have been spending great sums of money trying to foster the entrepreneurial process in their own regions, but the problem is that the economic perspectives and metrics copied when the policies are imported - university proximity, high technology jobs, number of patents, number of graduates - are not adequate for less developed localities and result in short-sighted policies that would have been more effective had the local context been taken into account as recommended by Schumpeter, whose focus is on fostering local innovative entrepreneurs (Hadjimanolis, 1999; Isenberg 2010; Stephens et al., 2013).

Proposition 2: The objectives and metrics of a public policy on innovation must be aligned with its target audience.

The objectives and metrics of a public policy on innovation must be aligned with the target audience it is aimed to reach (Bajmócy \& Gébert, 2014). The excessive focus put on technology leads to the implementation of policies which pay little attention to low and mid technology industries (Von Tunzelmann \& Acha, 2005). The problem is, only a small percentage of existing businesses are high-technology and $R \& D$-intensive enterprises (Tsuja \& Mariño, 2013). That means governments have implemented public policies on innovation which are little consistent with most small businesses and have, at the same time, put in the same group companies with different innovation contexts in an one-size-fits-all fashion that is detrimental and not viable to small businesses and regional development (Acs \& Audretsch, 1988, 2010; Albiol-Sanchez \& Van Stel, 2016; Gjelsvik, 2018; Stephens et al., 2013).

Proposition 3: Public policies on innovation for small businesses must promote the capture and assimilation of local knowledge.

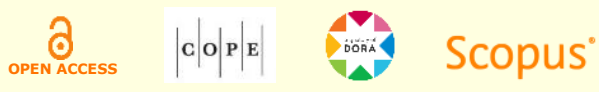


Innovation policies for the small businesses must promote the capture and assimilation of local knowledge (Autant-Bernard, Fadairo, \& Massard, 2013; Howells, 2005; Laranja, Uyarra, \& Flanagan, 2008; Roper et al., 2017; Tödtling \& Trippl, 2005), and policy-makers must pay attention to the social context in which the entrepreneurial activity is framed (Acs, Stam, Audretsch, \& O'Connor, 2017; Audretsch, 2015; Lee, Florida, \& Acs, 2004). England, for example, has created political structures aimed at addressing issues affecting local development and growth (Roper et al., 2017). As a result, the support mechanisms for these policies are geared towards local-based businesses, namely the small enterprises (Hildreth \& Bailey, 2013; Roper et al., 2017).

It is also necessary to understand that the discourse behind the policy must reflect its objectives and actions. For example, if the creation of a university in a poor locality is considered an innovation policy, the university's interaction with the local environment and its curricula must reflect the local context; if the academic programs do not help students to improve their own region, then it may be an evidence of inadequacies between discourse and practice (Stephens et al., 2013).

Proposition 4: Public policies on innovation for small businesses must have their focus on the manager/owner.

Policy-makers would be more successful had they started by formulating public policies on innovation for small businesses with a clear focus on the manager/owner as well as the business. For example, policy-makers in general develop policies aimed at improving the business environment, which in itself is more related to the life cycle and the organizational structure of the enterprise, when in fact they should focus on fostering the innovative potential of the individual as a person (Hampel-Milagrosa, Loewe, \& Reeg, 2015; Henrekson, 2014; Öner \& Kunday, 2016). Focusing on the manager/owner is a must (J. C. Carland, Carland, \& Stewart, 2015).

Policy-makers have also to keep in mind that opportunities present themselves differently to individuals throughout their lives, and that there can be no innovation in the absence of opportunities (Alvarez \& Barney, 2007; Alvarez, Barney, \& Anderson, 2013; Hampel-Milagrosa et al., 2015; Mrożewski \& Kratzer, 2017; Shane, 2012). For example, the qualification and formal education of the manager/owner are commonly pointed out as factors of success in small businesses (Fadahunsi, 2012; Franco \& Haase, 2010; Zaridis \& Mousiolis, 2014). However, most studies generally do not discuss that formal education and qualification are two factors that historically reveal a harsh social aspect, namely: individuals who hold less economic power and become entrepreneurs face more difficulties in accessing formal education and qualifying over time; likewise, individuals with lower economic power usually have lower quality formal education than individuals who come from better socioeconomic backgrounds. It means that the access to knowledge differs considerably among individuals (Carlsson et al., 2013).

The small business has a strong presence of its owner as a manager and decision-maker, so that all of the innovative efforts are determined by the owner himself or herself (Cooper, Peake, \&

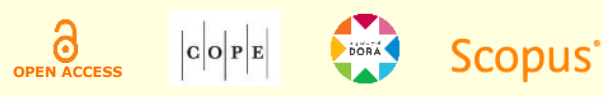


Watson, 2016; Romero \& Martínez-Román, 2012; Silva, Dacorso, \& Montenegro, 2016; Van Der Sluis, Van Praag, \& Vijverberg, 2008). That being said, it is understandable that personal traits or characteristics as well as the life trajectory of the manager/owner are determinants of the innovative success of the small business (Fadahunsi, 2012; Franco \& Haase, 2010; Garud, Gehman, \& Giuliani, 2014; Silva, Dacorso, \& Montenegro, 2016). In this context, we argue that policy-makers play an important role in developing strategies to foster the innovative capabilities of the small business through its manager/owner.

Proposition 5: Public policies on innovation for small businesses must consider the innovation profile of the small business.

Finally, public policies on innovation for small businesses must consider the innovation profile of such businesses (Bajmócy \& Gébert, 2014). As the innovative development is part of the dayto-day of small businesses, most of the innovations in such environments are generated according to the enterprises' own perspectives (Forsman, 2008, 2009; Hirsch-Kreinsen, 2008; MartínezRomán, \& Romero, 2013). Therefore, $R \& D$ or financial indicators do not reflect the typical innovative activities of the small enterprise (Crossan \& Apaydin, 2010; De Jong \& Marsili, 2006; Santamaría et al., 2009). Furthermore, policy-makers must develop public policies on innovation with adequate metrics for small businesses, such as service, process, organizational and market innovations, and also consider social externalities such as the welfare and local development of regions (Bajmócy \& Gébert, 2014; Forsman, 2011; Mirzanti et al., 2015; Silva, Dacorso, Costa, $\&$ Di Serio, 2016; Stephens et al., 2013).

\section{Methodology}

We adopted a qualitative documentary research as our research method (Saunders, Lewis, \& Thornill, 2009). We analyzed the adequacy of the public policies supporting innovation in small businesses in Brazil, using as our sources the data from the innovation policies' texts in Brazil's three spheres of government - federation, states, and municipalities - in force ${ }^{2}$ until December $31^{\text {st }}, 2017$. Specifically, we collected data from the following governing bodies' websites: (a) Ministries of the Federal Government and related bodies; (b) Secretaries of State Governments and their respective State Foundations for Research Support; and (c) Secretaries of City Halls of Brazilian State Capitals.

Based on our literature review, we adopted four criteria to identify and select public policies on innovation: (a) the focus on innovation had to be explicit - self-identified - in the policy's objective; (b) innovation had to be conceptualized as something new or improved and outcomeoriented; (c) the innovation policy had to be presented as a set of governmental activities translated into plans, programs, projects or actions; and (d) the policy had to be in force. We chose this approach because it enabled the analysis of policies at multiple - from national to local - levels of government-led policy-making. Besides, since the Federal Law of Access to Information (Lei n. 12.527, 2011) grants public access to information of general or collective interest, we

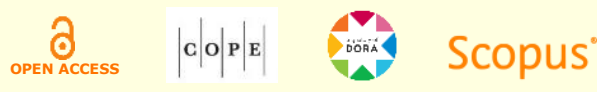


expected that all of the Brazilian public policies on innovation would be available for consultation, what resulted in 94 policies as our final sample.

We created a classification form in order to identify general aspects, characteristics of the target audience, and characteristics of the actions (Lundström \& Stevenson, 2005). The form was used in a previous study (Borges et al., 2018) and contains the following: (a) control number, (b) name of the policy, (c) type of policy, (d) year of creation, (e) objective, (f) responsible body, (g) target audience, (h) type of support offered, (i) agents involved, ( $\mathrm{j}$ ) local context, (k) intended results, (l) follow-up mechanisms, (m) policy impacts, (n) evaluation metrics, and (o) link to website.

We also created an individual form for each policy and later compiled all of the information obtained in a single Microsoft Excel sheet. Analysis was performed considering Bardin's (2011) phases for qualitative content analysis, a technique that works with words to generate inferences from the content communicated through a text, considering both the presence and the absence of characteristics in a given fragment of the message. These phases and each of the steps in our research are detailed in Table 1.

\section{Table 1}

\section{Operationalization phases of content analysis}

\begin{tabular}{lll}
\hline Phase & Meaning & Operationalization \\
\hline Pre-analysis & $\begin{array}{l}\text { Organization of the material } \\
\text { needed for interpretation }\end{array}$ & $\begin{array}{l}\text { We collected data about the public policies on innovation from } \\
\text { the following Brazilian governmental bodies: Ministries of } \\
\text { Federal Government and related bodies; Secretaries of States } \\
\text { and State Foundations for Research Support; and Secretaries } \\
\text { of City Halls of Brazilian State Capital cities. }\end{array}$ \\
\hline Material exploration & Coding of the raw material found & $\begin{array}{l}\text { We distributed the raw information for each policy in an } \\
\text { innovation policy classification form. }\end{array}$ \\
\hline $\begin{array}{l}\text { Treatment of the } \\
\text { information and } \\
\text { interpretation }\end{array}$ & $\begin{array}{l}\text { Categorical analysis to verify } \\
\text { similarities and differences, and } \\
\text { regrouping }\end{array}$ & $\begin{array}{l}\text { We compiled the information obtained in a single table and } \\
\text { proceeded to a comparative analysis of the innovation policies. }\end{array}$ \\
\hline
\end{tabular}

Note. Source: Adapted from Bardin, L. (2011). Análise de conteúdo. São Paulo, Brazil: Almedina.

\section{Results}

In the Pre-analysis phase, we collected data on the three government levels in Brazil by manually accessing the websites of Ministries, Secretaries and each related governmental body or entity, comprising every public policy on innovation in force in the country until December $31^{\text {st }} 2017$. At the federal level, we accessed the websites of 22 Ministries of Brazil and 122 bodies related to them that had explicit (self-identified) innovation policies. Although the websites generally have an actions and programs tab, most of the policies they mentioned could not be found. We used the keyword innovation alone and together with the keywords plan, program, project, action and small business in the search engines of the websites. Initially, we found 216 policies that mentioned innovation, of which only 119 were actual innovation policies. The other policies were focused on $R \& D$ and presented innovation as an externality of the actions undertaken, and

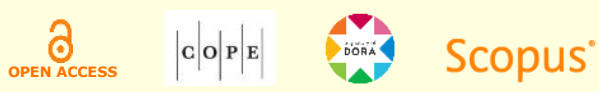


not as an objective of the policy itself. Of the 119 , only 54 policies were still in force as of December $31^{\text {st }} 2017$.

Following through, at the state level we accessed the websites of the 486 State Secretaries and 27 State Foundations for Research Support in the 26 states and the Federal District of Brazil. Only the websites of Secretaries from the States of Bahia, Minas Gerais, Rio de Janeiro and São Paulo presented an actions and programs tab, but likewise it was not possible to find most of the policies using such resource. We used the keywords in the search engines of the websites of all Brazilian States, and initially found 179 policies, of which 146 were in fact innovation policies, but only 33 were still in force as of December $31^{\text {st }} 2017$.

Finally, at the municipal level, we accessed the websites of 418 Secretaries of the 27 Brazilian State Capitals. The websites of Secretaries in 11 capitals - Rio Branco, Maceió, Fortaleza, Vitória, Cuiabá, João Pessoa, Curitiba, Porto Velho, Boa Vista, Aracaju, Palmas - were either offline or not working. The websites of the remaining 16 capitals did work, but did not present an actions and programs tab. We then used the keywords in the search engines of the websites and initially found 46 policies, of which 35 were in fact innovation policies, but only seven were still in force as of December $31^{\text {st }} 2017$.

In the Material Exploration phase, we arranged the information of every policy in a classification form, so that the material could be later codified. The content of the public policies on innovation at the three government levels is distributed between target audience, objectives and type of support offered. We found that the lower the governmental sphere, the less clear is the information available in the website. Surprisingly, across all the three levels of governance, the innovation policies are not clear when it comes to considering local contexts, intended results, follow-up mechanisms, impacts and evaluation metrics.

In the Treatment of the Information and Interpretation phase, we analyzed the innovation policies according to the categories established in the policy classification form (Table 1) and made a cross comparison of the 94 policies in our sample. Table 2 summarizes these results and points out the predominant characteristics of the public policies on innovation and for small businesses in Brazil at the three governmental levels. 
Table 2

Comparison of public policies on innovation across the three levels of governance

\begin{tabular}{|c|c|c|c|}
\hline & Federal & State & Municipality \\
\hline Number of policies & 54 & 33 & 7 \\
\hline Type of policy & Programs & Programs & Programs \\
\hline Year of creation & 2009 to 2017 & 2009 to 2017 & 2009 to 2017 \\
\hline Objective & Clear & Clear & Clear \\
\hline Responsible body & $\begin{array}{l}\text { Ministry of Science, } \\
\text { Technology, Innovation and } \\
\text { Communications }\end{array}$ & $\begin{array}{l}\text { Secretaries of Technology and } \\
\text { Development }\end{array}$ & $\begin{array}{l}\text { Secretaries of Technology and } \\
\text { Development }\end{array}$ \\
\hline Target audience & Generalist & Generalist & Small Businesses \\
\hline Type of support & Financial & Financial & Beyond financial \\
\hline Agents involved & Mentioned & Not mentioned & Not mentioned \\
\hline Local context & Not mentioned & Not mentioned & Not mentioned \\
\hline Intended results & $\begin{array}{l}\text { Technological innovation } \\
\text { Not specified }\end{array}$ & $\begin{array}{l}\text { Technological innovation } \\
\text { Specified }\end{array}$ & $\begin{array}{l}\text { Technological innovation } \\
\text { Specified }\end{array}$ \\
\hline $\begin{array}{l}\text { Follow-up } \\
\text { mechanisms }\end{array}$ & Not mentioned & Not mentioned & Mentioned \\
\hline Impacts & Economical and financial & Economical and financial & Social, economic and financial \\
\hline Metrics & Classical & Classical & Classical and others \\
\hline Economic view & Classical & Schumpeterian & Schumpeterian \\
\hline Access & Difficult & Difficult & Difficult \\
\hline
\end{tabular}

We found an overwhelming presence of innovation policies with the same characteristics, and then we performed three temporal cuts that best represented them, as they emerged from the field work: (a) prior to 2002, (b) between 2003 and 2008, and (c) between 2009 and 2017. This time-framing considers the presence and grouping of policies with similar characteristics, and 2009 as the year the $\mathrm{FNDCT}^{3}$ added the term innovation to its mission objective.

Innovation policies at all government levels prior to 2002 are focused on $R \& D$ and applied research. Policies created between 2003 and 2008 have a structuring character and were marked by the creation of legal - laws and decrees - and economic - sectorial programs - bases to boost innovation in the country. And policies created between 2009 and 2017 are diverse and with greater presence of small business policies.

The time cut with greater number of policies in all governmental levels was the period between 2009 and 2017, which means that the public policies on innovation in Brazil are recent. The 2009 period coincides with the year in which the FNDCT - a national fund responsible for the resources destined to innovation in the country - added the term innovation to its objective, ultimately impacting every public policy on innovation created since then, which perhaps explains the higher concentration of policies in the post-2009 time period. 
At the federal sphere, the Ministries of Brazil and related bodies mention innovation as important for the development of the country and use innovation as a pillar for the activities that are developed. However, in practice, such information is not translated into plans, programs, projects or actions. Many ministries and related bodies do not have innovation policies and most policies focus on specific innovation support bodies rather than focusing on a bigger, nation-wide, innovation policy. Likewise, other policies have the potential for innovation, but are not selfidentified as innovation policies. The information available for each policy is also incipient. Given that the documents represent the bridge between the policy and the target audience, it is where all the information about a policy should be found. However, the lack of clear guidelines creates policies that are not properly aligned with the achievement of concrete innovation outcomes.

At the state sphere, the websites of State Secretaries and their respective State Foundations for Research Support do not mention innovation as something important for the development of the states nor as a pillar for their economic activities. State-level websites lack more information when compared to federal-level websites, and State Foundations for Research Support work more as bodies to replicate federal innovation policies rather than creating their own. We could not find individual innovation and science and technology plans at the state level, and, while the regional plans mention big investments on innovation, there is no clear policy structure at the state level, as they basically replicate federal-level policies and focus on $R \& D$ investment rather than innovation itself. Thus, strategic objectives at the state-level do not translate into effective innovation policies.

At the municipal sphere, the number of mentions to innovation by the local secretaries as something important or strategic at the city-level is scarce. There is a lack of public policies on innovation and most links to the websites are either broken or offline, with information mostly focused on the local political figurehead rather than the local public policies on innovation or other important issues.

Even though the predominant economic view at the state and municipal spheres was found to be Schumpeterian, the socio-historical context of the policies' creation as well as the conjunctural vision of the policies as a whole suggest that innovation is not employed at federal, state nor municipal level strategically.

An innovation policy should ideally be responsible for the building of a strong nation, and also enable the exploration of the innovative potential of its regions at the local level. However, the Brazilian public policies on innovation are by and large limited to financial support policies in general. Only at the municipal level one can find predominance of policies supporting the small businesses, but given the small number of municipal policies - only seven policies - it is arguably not enough to call the municipal view Schumpeterian.

Getting back to our five propositions on the fundamental aspects that characterize an adequate public policy on innovation for the small businesses, we found the following:

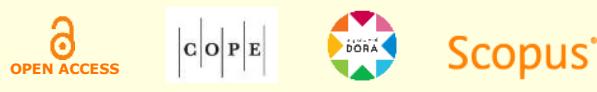


Proposition 1: Public policies on innovation must focus on local and regional development, ${ }^{4}$ but the Brazilian policies are not focused on the local context. The content of the policies does not present any information as to the context of the policy formulation nor which federal, state or municipal characteristics justify their creation. Also, they do not explore sufficiently why the policy would be adequate to its target audience nor how targeting such audience would benefit the country or region. Equally, policies on innovation in Brazil do not demonstrate integration with a socioeconomic growth purpose at any governmental level, nor are they integrated to each other at the different governmental levels. As a result, they fail to explore a region's innovative potential once the potential is largely unknown.

Proposition 2: The objectives and metrics of a public policy on innovation must be aligned with its target audience, but in practice policy-makers do not consider the innovation contexts. As a result, evaluation metrics and follow-up mechanisms are inadequate, thus hampering the transformation of objectives into results. That is because policy-makers have developed rather generalist innovation metrics in our public policies on innovation for different contexts.

Proposition 3: Public policies on innovation for small businesses must promote the capture and assimilation of local knowledge, ${ }^{5}$ but the Brazilian policies are not locally oriented, they are focused on technological innovation and measured in terms of classical evaluation metrics and on their economic and financial impacts. Policy-makers are yet to develop public policies on innovation considering the social relevance of small businesses. For example, only the policies VAI TEC (in the southeastern state of São Paulo) and Projeto Intercaju (in the northeastern state of Ceará) are totally adherent to such propositions, as in both cases the local context is the pillar of the policy, and innovation is the engine for social development and transformation of the locality.

Proposition 4: Public policies on innovation for small businesses must have their focus on the manager/owner, but only nine policies we analyzed had the manager/owner as their focus: at the federal level, Agentes Locais de Inovação and InovAtiva Brasil; at the state level, Projeto Intercaju, Minas Digital, Inventiva and Programa Startup Rio; at the municipal level, Programa de Incentivo Fiscal à Inovação, Programa de Fomento e Pré-Aceleração de Startups and VAI TEC. That is preoccupying, because the innovative process in a smaller, less structured business generally reflects its owner's lack of institutional support. This in turn creates less developed cities and a vicious cycle of social injustice, as noticed in most Brazilian municipalities. As a result, the public policies on innovation for small businesses in Brazil do not reflect the organizational characteristics of the small businesses, and as such lack effectiveness.

Proposition 5: Public policies on innovation for small businesses must consider the innovation profile of the small business, ${ }^{6}$ but the Brazilian policies lack a focus on the characteristics of small businesses and the specificities of such target audience by adopting criteria that would be more adequate to big businesses instead. This suggests that policy-makers have limited knowledge on innovation, small businesses and entrepreneurship, which in turn demands more adequate public policies when it comes to the profile of the small business. For example, only the municipality of São Paulo has a specific secretary (Secretaria do Desenvolvimento, Trabalho, e

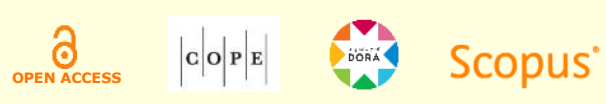


Empreendedorismo de São Paulo) and corresponding policies aimed at small businesses (Tech Sampa and VAI TEC).

In sum, most public policies on innovation in Brazil make use of classic evaluation metrics and do not consider the social externalities that innovation could potentially generate. The policies borrow metrics from the context of big businesses and erroneously try to apply them to small businesses. Furthermore, there is a small number of public policies on innovation aimed at small businesses: nine at the federal level, nine at the state level, and five at the municipal level. At the federal level, the Ministry of Small Businesses was extinct in 2015, and at the state level only Amapá, Pernambuco and Piauí have Secretaries focused on small businesses and entrepreneurship in general. At the municipal level, only São Paulo has such Secretary, which means that the small businesses' context is not integrated into the economic development model adopted by the Brazilian public policies on innovation.

It is worthwhile to mention that, in the $2016-2017$ periods, a staggering number of 206 out of 300 public policies on innovation were discontinued nationwide. In our initial search, only 54 of 119 policies were in force at the federal level; only 33 of 146 policies were in force at the state level; and only seven of 35 policies were in force at the municipal level. This period of policy discontinuation coincides with the grave economic and political crisis in Brazil.

We argue that, if innovation has the potential to help resolving economic and social problems, the dismantling of the innovation policies by the political forces reinforces the idea that innovation is not seen as strategically in either governmental sphere. Besides, most of our innovation policies are recent, which perhaps means that planning horizons are limited by the political term of policy-makers, with no attention to the path-dependency's influence on the nation's creation of innovations. Thus, there is not a visible joint effort to create innovation policies aligned with socioeconomic development and of the nation's interests.

\section{Discussion}

The Brazilian innovation policies do not consider the local context. The formulation of innovation policies disconnected from the local context ends up generating predatory policies and increasing the social and economic gap between the regions (Autio et al., 2014; Bajmócy \& Gébert, 2014; Barkhatov et al., 2016; Stephens et al., 2013). Brazil has been facing a serious political and crippling economic crisis which has culminated in the bankruptcy or declared financial calamity of six states, while a difficult or critical fiscal situation amounts to $86 \%$ of Brazilian municipalities (Federação das Indústrias do Estado do Rio de Janeiro [FIRJAN], 2017; Rodrigues, 2019). The lack of innovation policies aligned with the local context may have contributed to the low responsiveness of the regions, as policy-makers seem to have failed to see innovation as a way out of the crisis by making cities more sustainable.

Because policy-makers do not take into account the context of innovation, evaluation metrics are inadequate and, ultimately, there are no follow-up mechanisms capable of turning objectives into results. This means that policy-makers have not focused on what mechanisms lead to innovation,
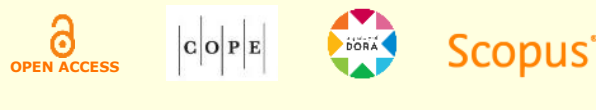
having instead used a one-size-fits-all approach to policy-making that is damaging regional development (Acs \& Audretsch, 1988, 2010; Albiol-Sanchez \& Van Stel, 2016; Gjelsvik, 2018; Stephens et al., 2013).

Other studies on innovation and entrepreneurship policies in different countries ${ }^{7}$ have also found that governments tend to develop short-sighted national innovation policies trying to emulate the best practices of regions or sectors with better innovation performance, thus not considering the local context (Howells, 2005; Isenberg, 2010; Tödtling \& Trippl, 2005). By studying former Soviet countries and their transition to capitalism, Veugelers and Schweiger (2016) conclude that there are specific country conditions which call for "sufficiently tailored" (p. 258) innovation policies, away from the one-size-fits-all or best-practice approaches, instead focusing on capacity building. By studying technological clusters in the US and UK, on the other hand, Etzkowitz (2012) also concludes that the best-practice mode as applied to innovation policy cannot work given the different dynamics of regions, and argues that successful clusters are successful thanks to policies allowing the permeability (knowledge flow) among universityindustry-government boundaries.

The socio-historical context of policy creation and economic vision as seen in the documents produced by the responsible governmental bodies in our study indicates an economic view which is based on classical economic theory. As such, policy-makers tend to believe that socioeconomic development will naturally be achieved by just correcting market failures, so that agents are only responsible for the correct allocation of resources (Costa, 2016). As a result, instead of creating opportunities, current policies only reinforce the existing paradigm. There is also a lack of incentives to the activities that lead to innovation, which is troublesome as innovation depends of policies aimed at changing the existing structure so that innovation capabilities could be built upon a strong innovative environment.

Of the 94 Brazilian innovation policies we analyzed, only 23 focus on small businesses. Since small businesses are considered the ideal type of organization and are primarily responsible for the economic and social development of most regions, municipalities should have been more proactive when it comes to creating innovation policies for small businesses locally. However, the number of innovation policies in Brazil for the small enterprise at the local, city level, has been negligible to say the least.

The social abysm between the municipalities seems to be the result of the governments' incapacity to act locally. The small businesses are responsible for local economic dynamics and, as such, are an answer to poverty reduction (Bajmócy \& Gébert, 2014; Barkhatov et al., 2016; Gardner, 1961). Fostering adequate public policies on innovation for small businesses might be an important strategy to get a country out of its swinging economy aspect and the vicious cycle of social inequality.

Ramos-Mejía, Franco-Garcia and Jauregui-Becker (2018) discuss examples of technological changes in contexts such as Thailand ${ }^{8}$ to argue that the biggest challenge to innovation and poverty reduction in developing countries is the overcoming of ill-functioning institutions such

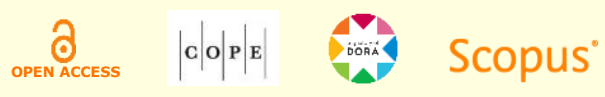


as the grip to power and corruption created and maintained by the political elite. Equally, George, Rao-Nicholson, Corbishley and Bansal (2015) have studied a public-private partnership initiative focused in emergency medical response in India, ${ }^{9}$ arguing that such partnership was of utmost importance where the government failed, because by joining the strengths of the public and private sectors it was possible to empower communities living at the base of the pyramid.

\section{Conclusion}

Existing innovation policies proved to be inadequate for the development of the small business and the country. Brazil has very few innovation policies, concentrated in the federal level and scarce at the bottom, municipal level. The low number of innovation policies in the capitals allows us to further question how innovation is treated in the other, much smaller Brazilian municipalities in the countryside, whose economic and social problems are even greater. We must remember that socioeconomic development and innovation go hand in hand. The lack of public policies on innovation might explain the low competitiveness in municipalities and reflects the lack of political will to solving the problems that cripple the country. The same occurs across all other governmental spheres.

A prosperous nation, based on the principles of social welfare and equality, reflects its governmental institutions. Swinging economies such as Brazil, India, Thailand and former Soviet nations have experienced fast economic growth and have invested a considerable amount of public resources on innovation, but yet have failed to tackle problems such as poverty. In these economies, wealth is not equally distributed among their populations, and innovation policies have been noted as bad, short-sighted, ineffective and sometimes biased or even corrupt. Brazil, for example, has been facing a serious political and economic crisis, and the lack of adequate innovation policies for the country and the small businesses may explain the country's low capacity to deal with the crisis. As a result, Brazil lost positions in the Global Competitiveness Index, dropping from the $48^{\text {th }}$ position in 2012 to the $72^{\text {nd }}$ position in 2018 (World Economic Forum [WEF], 2018), and in the Global Innovation Index, dropping from the $47^{\text {th }}$ position in 2011 to the $68^{\text {th }}$ position in 2018 (Cornell University, INSEAD, \& WIPO, 2018).

As a theoretical contribution, we analyzed the adequacy of public policies on innovation for the small businesses according to five previously stated propositions derived from the literature review. The literature of public policies on innovation largely overlooks the adequacy of policies and lacks a reasonable questioning of the policy formulation process. As a result, many public policies lack effectiveness and miss their target audience (Bajmócy \& Gébert, 2014). Our five propositions may be used as starting points for researchers interested in studying both public policies on innovation in general and specific policies for small businesses as proxies for adequacy. In doing so, we have extended our understanding on the what and how of public policies on innovation, and hope to have contributed by extending the literature in this research domain.

To researchers, we suggest a few topics that might be explored further: (a) to question the adequacy of the innovation policies developed in a country; (b) to investigate the role of innovation policies in poverty reduction; (c) to investigate the role of small businesses in a

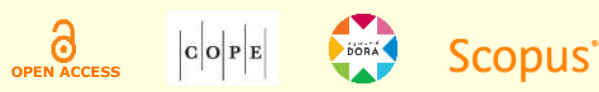


country's economic and social development; (d) to consider the influence of the manager in the innovation activity of the small business; (e) to adopt the small, traditional, low-tech business as an object of study; and ( $f$ ) to investigate how the inequality of opportunities affects the entrepreneurial activity. In this research, we have limited ourselves to studying the current innovation policies. Therefore, we do not present a historical perspective. We believe that such a perspective may deepen the discussion, so we also leave it as a suggestion for future research.

As a practical contribution, our results may help promoting the formulation of innovation policies in small businesses, which in turn may improve a country's competitiveness and socioeconomic development. Aiming to contribute with the innovative activity in Brazil and other developing countries with similar structural problems, we recommend that policy-makers: (a) introduce innovation in the strategies for economic and social development of regions and localities; (b) use Schumpeterian theory in the process of policy formulation; (c) consider the small business as the ideal type of organization for the economy, especially in poorly developed regions; (d) look for prior knowledge on policy formulation and on the context where innovation occurs; (e) specify where the activities - and metrics - of research, development and innovation begin and end; (f) integrate innovation and entrepreneurship policies; (g) create a unified, online platform with all innovation policies separated by governmental sphere, target public and type of support offered, so as to make the access to information easier; (h) offer more detailed information regarding the local context, intended results, monitoring mechanisms, impacts and evaluation metrics of the policies and how to access them; (i) consider non-technological innovation; ( $\mathrm{j}$ ) understand that a policy of financial support must be accompanied by technical, managerial and human support; $(\mathrm{k})$ create more transparent follow-up mechanisms for each innovation policy; and (l) use appropriate metrics for each target audience.

This research is limited mainly by its source of information - namely, governmental websites for the documentary analysis, which in itself was dependent on the availability of data that was scarce in certain federative entities, so there may be that some policies went unnoticed as some websites - especially at the municipal level - were offline. Also, given its qualitative nature, we expect our study to be analytically but not statistically generalizable, as public policies are contextdependent.

\section{Notes}

\footnotetext{
${ }^{1}$ We chose Brazil as a proxy to study public policies on innovation and small businesses in a swinging economy for a few reasons, namely: (a) Sen (2010) singles out Brazil as one example of a country that was successful in fast economic growth, but has failed to redistribute its benefits to the poor; (b) the country has been facing its longest and most severe recession, thus dropping several rankings in global competitiveness and innovation indexes (Cornell University et al., 2018; WEF, 2018); (c) Brazil remains one of the most unequal countries in the world since the 1980s, with the most recent data suggesting the country's $10 \%$ richest receive more than $55 \%$ of the national income share (Alvaredo, Chancel, Piketty, Saez, \& Zucman, 2017).

${ }^{2}$ We use the term in force as per its meaning of something "being in effective operation" (In force, n.d.).

${ }^{3}$ FNDCT (Fundo Nacional de Desenvolvimento Científico e Tecnológico) is Brazil's national fund for scientific and technological development.
}

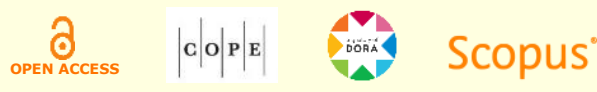


${ }^{4}$ A successful policy in one locality may be a failure in another. This is because the success of a policy depends on the context surrounding it, so the replication logic of copying a policy may be useless if it is not context-oriented. In swinging economies such as African countries, which have less mature institutions, the policy formulation process is not aligned according to the interests of both rulers and subjects, so there is neither an institutional nor an outside solution for the economic development of such countries (Deaton, 2017).

${ }^{5}$ Especially in swinging economies, a public policy can hardly be effective in terms of economic development if not coupled with basic social change (Drèze \& Sen, 1999). The problem is that badly formulated policies disregard the social aspects of development and rather focus in economic metrics and pillars, thus overlooking the real horrors of poverty (Deaton, 2017; Drèze \& Sen, 1999). This is where the social role of innovation in the small business and context-oriented, bottom-up policy-making may give the support a country needs to prosper.

${ }^{6}$ In the context of swinging economies and developing countries, the small business may be a local answer to socioeconomic development, given its capability of implementing local solutions - such as Indian jugaad, Brazilian gambiarra, and Chinese chuangxin, all some sort of bricolage in their own contexts - to local problems (Deaton, 2017; George et al., 2015; Pansera \& Martinez, 2017).

${ }^{7}$ For example: Isenberg (2010) points out that even though certain extremely poor and war-torn nations such as Rwanda in Africa have been successful in creating entrepreneurial ecosystems and reduced poverty considerably, with job creations and GDP-growth, most of the governments in emerging and developing economies fail because they develop unattainable goals as a result of bad policy-making practices.

${ }^{8}$ Thailand is a good example in East Asia, because even though there is a nascent university-industry linkage as part of its National Innovation System (NIS), top-down policy-making, corruption, bad use of public funds, as well as institutional barriers hamper its development and result in a weak, fragmented and unsustainable NIS (Intarakumnerd, Chairatana, \& Tangchitpiboon, 2002; Ramos-Mejía, Franco-Garcia, \& Jauregui-Becker, 2018; Schiller, 2006).

${ }^{9}$ India is another example of a country with one of the fastest economic growth but that has also failed to distribute wealth among its population. India has more than one Brazil of poor people, and half of them are chronically poor and will remain poor forever (Mahapatra, 2017; OXFAM International, n.d.). Bad policy approaches and ill-fitted "narratives of innovation" (Pansera \& Martinez, 2017, p. 5) are singled out as reasons to the chronicity of poverty in India (Mehta \& Shah, 2003; Pansera \& Martinez, 2017).

\section{References}

Acs, Z. J., \& Audretsch, D. B. (1988). Innovation in large and small firms: An empirical analysis. The American Economic Review, 78(4), 678-690.

Acs, Z. J., \& Audretsch, D. B. (2010). Introduction to the $2^{\text {nd }}$ edition of the handbook of entrepreneurship research. In Z. J. Acs, \& D. B. Audretsch (Eds.), Handbook of entrepreneurship research (pp. 1-19). New York, NY: Springer.

Acs, Z. J., Stam, E., Audretsch, D. B., \& O’Connor, A. (2017). The lineages of the entrepreneurial ecosystem approach. Small Business Economics, 49(1), 1-10. https://doi.org/10.1007/s11187-017-9864-8

Acs, Z. J., \& Szerb, L. (2007). Entrepreneurship, economic growth and public policy. Small Business Economics, $28(2-$ 3), 109-122. https://doi.org/10.1007/s11187-006-9012-3

Albiol-Sanchez, J., \& Van Stel, A. (2016). Investigating the impact of small versus large firms on economic performance of countries and industries. In D. Bögenhold, J.-P. Bonnet, M. Dejardin, \& D. Garcia Pérez de Lema (Eds.), Contemporary entrepreneurship (pp. 51-73). New York, NY: Springer.

Aldrich, H. E. (2012). The emergence of entrepreneurship as an academic field: A personal essay on institutional entrepreneurship. Research Policy, 41(7), 1240-1248. https://doi.org/10.1016/j.respol.2012.03.013

Alvaredo, F., Chancel, L., Piketty, T., Saez, E., \& Zucman, G. (2017). World inequality report 2018. Retrieved from https://wir2018.wid.world/

Alvarez, S. A., \& Barney, J. B. (2007). Discovery and creation: Alternative theories of entrepreneurial action. Strategic Entrepreneurship Journal, 1(1-2), 11-26. https://doi.org/10.1002/sej.4

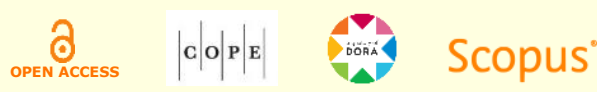


Alvarez, S. A., Barney, J. B., \& Anderson, P. (2013). Forming and exploiting opportunities: The implications of discovery and creation processes for entrepreneurial and organizational research. Organization Science, 24(1), 301 317. https://doi.org/10.1287/orsc. 1110.0727

Audretsch, D. B. (2015). Everything in its place: Entrepreneurship and the strategic management of cities, regions, and states. New York, NY: Oxford University Press.

Audretsch, D. B., \& Link, A. N. (2012). Entrepreneurship and innovation: Public policy frameworks. The Journal of Technology Transfer, 37(1), 1-17. https://doi.org/10.1007/s10961-011-9240-9

Autant-Bernard, C., Fadairo, M., \& Massard, N. (2013). Knowledge diffusion and innovation policies within the European regions: Challenges based on recent empirical evidence. Research Policy, 42(1), 196-210. https://doi.org/10.1016/j.respol.2012.07.009

Autio, E., Kenney, M., Mustar, P., Siegel, D., \& Wright, M. (2014). Entrepreneurial innovation: The importance of context. Research Policy, 43(7), 1097-1108. https://doi.org/10.1016/j.respol.2014.01.015

Bajmócy, Z., \& Gébert, J. (2014). The outlines of innovation policy in the capability approach. Technology in Society, 38, 93-102. https://doi.org/10.1016/j.techsoc.2014.02.004

Bardin, L. (2011). Análise de conteúdo. São Paulo, Brazil: Almedina.

Barkhatov, V., Pletnev, D., \& Campa, A. (2016). Key success factors and barriers for small businesses: Comparative analysis. Procedia-Social EF Behavioral Sciences, 221, 29-38. https://doi.org/10.1016/j.sbspro.2016.05.087

Berends, H., Jelinek, M., Reymen, I., \& Stultiëns, R. (2014). Product innovation processes in small firms: Combining entrepreneurial effectuation and managerial causation. Journal of Product Innovation Management, 31(3), 616-635. https://doi.org/10.1111/jpim.12117

Bhupatiraju, S., Nomaler, Ö., Triulzi, G., \& Verspagen, B. (2012). Knowledge flows: Analyzing the core literature of innovation, entrepreneurship and science and technology studies. Research Policy, 41(7), 1205-1218. https://doi.org/10.1016/j.respol.2012.03.011

Borges, C., Bezerra, É. D., Silva, G., Andreassi, T., \& Ferreira, V. R. S. (2018). Entrepreneurship policy in Brazil: Its focus and gaps. International Journal of Entrepreneurship $\mathbb{E}$ Small Business, 34(2), 183-203. https://doi.org/10.1504/ijesb.2018.10013257

Brush, C. G., \& Chaganti, R. (1999). Businesses without glamour? An analysis of resources on performance by size and age in small service and retail firms. Journal of Business Venturing, 14(3), 233-257. https://doi.org/10.1016/s0883-9026(97)00103-1

Bruton, G. D., Ahlstrom, D., \& Obloj, K. (2008). Entrepreneurship in emerging economies: Where are we today and where should the research go in the future. Entrepreneurship Theory $\mathcal{E}$ Practice, 32(1), 1-14. https://doi.org/10.1111/j.1540-6520.2007.00213.x

Bygrave, W., \& Minniti, M. (2000). The social dynamics of entrepreneurship. Entrepreneurship Theory Eु Practice, 24(3), 25-36. https://doi.org/10.1177\%2F104225870002400302

Carland, J. C., Carland, J. W., \& Stewart, W. H. (2015). Seeing what's not there: The enigma of entrepreneurship. Journal of Small Business Strategy, 7(1), 1-20. $\quad$ Retrieved from https://libjournals.mtsu.edu/index.php/jsbs/article/view/326/304

Carland, J. W., Hoy, F., Boulton, W. R., \& Carland, J. A. C. (1984). Differentiating entrepreneurs from small business owners: A conceptualization. Academy of Management Review, 9(2), 354-359. https://doi.org/10.2307/258448

Carlsson, B., Braunerhjelm, P., McKelvey, M., Olofsson, C., Persson, L., \& Ylinenpää, H. (2013). The evolving domain of entrepreneurship research. Small Business Economics, 41(4), 913-930. https://doi.org/10.1007/s11187013-9503-y

Cooper, D., Peake, W., \& Watson, W. (2016). Seizing opportunities: The moderating role of managerial characteristics on the relationship between opportunity-seeking and innovation efficacy in small businesses. Journal of Small Business Management, 54(4), 1038-1058. https://doi.org/10.1111/jsbm.12228 
Cornell University, INSEAD, \& WIPO. (2018). Global innovation index 2018: Energizing the world with innovation. Retrieved from https://www.wipo.int/edocs/pubdocs/en/wipo_pub_gii_2018.pdf

Costa, A. B. (2016). Teoria econômica e política de inovação. Revista de Economia Contemporânea, 20(2), 281-307. https://doi.org/10.1590/198055272024

Crossan, M. M., \& Apaydin, M. (2010). A multi-dimensional framework of organizational innovation: A systematic review of the literature. Journal of Management Studies, 47(6), 1154-1191. https://doi.org/10.1111/j.14676486.2009.00880.x

Damanpour, F. (2014). Footnotes to research on management innovation. Organization Studies, 35(9), 1265-1285. https://doi.org/10.1177/0170840614539312

Damanpour, F., \& Wischnevsky, J. D. (2006). Research on innovation in organizations: Distinguishing innovationgenerating from innovation-adopting organizations. Journal of Engineering $\mathcal{E}$ Technology Management, 23(4), 269. 291. https://doi.org/10.1016/j.jengtecman.2006.08.002

De Jong, J. P. J., \& Marsili, O. (2006). The fruit flies of innovations: A taxonomy of innovative small firms. Research Policy, 35(2), 213-229. https://doi.org/10.1016/j.respol.2005.09.007

Deaton, A. (2017). A grande saída: Saúde, riqueza e as origens da desigualdade. Rio de Janeiro, Brazil: Intrínseca.

Drèze, J., \& Sen, A. (1999). India: Economic development and social opportunity. New York, NY: Oxford University Press.

Etzkowitz, H. (2012). Triple helix clusters: Boundary permeability at university-industry-government interfaces as a regional innovation strategy. Environment $\mathcal{E}$ Planning C: Government $\mathcal{E}$ Policy, 30(5), 766-779. https://doi.org/10.1068/c1182

Fadahunsi, A. (2012). The growth of small businesses: Towards a research agenda. American Journal of Economics $\mathcal{E}$ Business Administration, 4(1), 105-115. https://doi.org/10.3844/ajebasp.2012.105.115

Fagerberg, J., Fosaas, M., \& Sapprasert, K. (2012). Innovation: Exploring the knowledge base. Research Policy, 41(7), 1132-1153. https://doi.org/10.1016/j.respol.2012.03.008

Fagerberg, J., Landström, H., \& Martin, B. R. (2012). Exploring the emerging knowledge base of 'the knowledge society'. Research Policy, 41(7), 1121-1131. https://doi.org/10.1016/j.respol.2012.03.007

Federação das Indústrias do Estado do Rio de Janeiro. (2017). Indice FIRJAN de gestão fiscal. Retrieved from https://www.firjan.com.br/ifgf/consulta-ao-indice/

Ferreira, J. J. M., Fernandes, C. I., Alves, H., \& Raposo, M. L. (2015). Drivers of innovation strategies: Testing the Tidd and Bessant (2009) model. Journal of Business Research, 68(7), 1395-1403. https://doi.org/10.1016/j.jbusres.2015.01.021

Forsman, H. (2008). Business development success in SMEs: A case study approach. Journal of Small Business Eु Enterprise Development, 15(3), 606-622. https://doi.org/10.1108/14626000810892382

Forsman, H. (2009). Improving innovation capabilities of small enterprises: Cluster strategy as a tool. International Journal of Innovation Management, 13(2), 221-243. https://doi.org/10.1142/s1363919609002273

Forsman, H. (2011). Innovation capacity and innovation development in small enterprises: A comparison between the manufacturing and service sectors. Research Policy, 40(5), 739-750. https://doi.org/10.1016/j.respol.2011.02.003

Franco, M., \& Haase, H. (2010). Failure factors in small and medium-sized enterprises: Qualitative study from an attributional perspective. International Entrepreneurship $\mathcal{E}$ Management Journal, 6(4), 503-521. https://doi.org/10.1007/s11365-009-0124-5

Freel, M. S. (2005). Patterns of innovation and skills in small firms. Technovation, 25(2), 123-134. https://doi.org/10.1016/s0166-4972(03)00082-8

Garcia, R., \& Calantone, R. (2002). A critical look at technological innovation typology and innovativeness terminology: A literature review. Journal of Product Innovation Management, 19(2), 110-132. https://doi.org/10.1111/1540-5885.1920110

Gardner, J. W. (1961). Excellence: Can we be equal and excellent too? New York, NY: Harper \& Row.

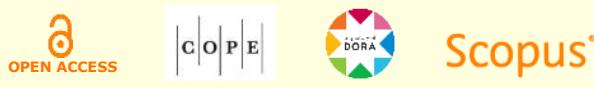


Garud, R., Gehman, J., \& Giuliani, A. P. (2014). Contextualizing entrepreneurial innovation: A narrative perspective. Research Policy, 43(7), 1177-1188. https://doi.org/10.1016/j.respol.2014.04.015

George, G., Rao-Nicholson, R., Corbishley, C., \& Bansal, R. (2015). Institutional entrepreneurship, governance, and poverty: Insights from emergency medical response services in India. Asia Pacific Journal of Management, 32(1), 39-65. https://doi.org/10.1007/s10490-014-9377-9

Gjelsvik, M. (2018). Universities, innovation and competitiveness in regional economies. International Journal of Technology Management, 76(1-2), 10-31. https://doi.org/10.1504/ijtm.2018.10009596

Hadjimanolis, A. (1999). Barriers to innovation for SMEs in a small less developed country (Cyprus). Technovation, 19(9), 561-570. https://doi.org/10.1016/s0166-4972(99)00034-6

Hampel-Milagrosa, A., Loewe, M., \& Reeg, C. (2015). The entrepreneur makes a difference: Evidence on MSE upgrading factors from Egypt, India, and the Philippines. World Development, 66, 118-130. https://doi.org/10.1016/j.worlddev.2014.08.005

Henrekson, M. (2014). Entrepreneurship, innovation, and human flourishing. Small Business Economics, 43(3), 511 528. https://doi.org/10.1007/s11187-014-9551-y

Hervas-Oliver, J.-L., Garrigos, J. A., \& Gil-Pechuan, I. (2011). Making sense of innovation by R\&D and non-R\&D innovators in low technology contexts: A forgotten lesson for policymakers. Technovation, 31(9), 427-446. https://doi.org/10.1016/j.technovation.2011.06.006

Hildreth, P., \& Bailey, D. (2013). The economics behind the move to 'localism' in England. Cambridge Journal of Regions, Economy Ė Society, 6(2), 233-249. https://doi.org/10.1093/cjres/rst004

Hirsch-Kreinsen, H. (2008). "Low-tech" innovations. Industry $\mathcal{E} \quad$ Innovation, 15(1), 19-43. https://doi.org/10.1080/13662710701850691

Howells, J. (2005). Innovation and regional economic development: A matter of perspective? Research Policy, 34(8), 1220-1234. https://doi.org/10.1016/j.respol.2005.03.014

Huggins, R., \& Thompson, P. (2014). A network-based view of regional growth. Journal of Economic Geography, 14(3), 511-545.

Huggins, R., \& Thompson, P. (2015). Entrepreneurship, innovation and regional growth: A network theory. Small Business Economics, 45(1), 103-128. https://doi.org/10.1007/s11187-015-9643-3

Huggins, R., \& Williams, N. (2011). Entrepreneurship and regional competitiveness: The role and progression of policy. Entrepreneurship $\mathbb{E} \quad$ Regional Development, $23(9-10), \quad 907-932$. https://doi.org/10.1080/08985626.2011.577818

In force. (n.d.). In Merriam-Webster's online dictionary. Retrieved from https://www.merriamwebster.com/dictionary/in\%20force

Intarakumnerd, P., Chairatana, P.-A., \& Tangchitpiboon, T. (2002). National innovation system in less successful developing countries: The case of Thailand. Research Policy, 31(8-9), 1445-1457. https://doi.org/10.1016/s00487333(02)00074-4

Isenberg, D. J. (2010, June). How to start an entrepreneurial revolution. Harvard Business Review, 88(6), 40-50. Retrieved from https://hbr.org/2010/06/the-big-idea-how-to-start-an-entrepreneurial-revolution

Keupp, M. M., Palmié, M., \& Gassmann, O. (2012). The strategic management of innovation: A systematic review and paths for future research. International Journal of Management Reviews, 14(4), 367-390. https://doi.org/10.1111/j.1468-2370.2011.00321.x

Landström, H., Åström, F., \& Harirchi, G. (2015). Innovation and entrepreneurship studies: One or two fields of research? International Entrepreneurship Ë Management Journal, 11(3), 493-509. https://doi.org/10.1007/s11365013-0282-3

Landström, H., \& Harirchi, G. (2018). The social structure of entrepreneurship as a scientific field. Research Policy, 47(3), 650-662. https://doi.org/10.1016/j.respol.2018.01.013

Landström, H., Harirchi, G., \& Åström, F. (2012). Entrepreneurship: Exploring the knowledge base. Research Policy, 41(7), 1154-1181. https://doi.org/10.1016/j.respol.2012.03.009

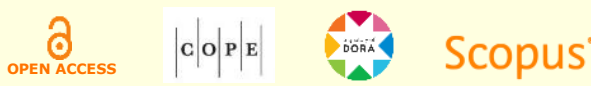


Laranja, M., Uyarra, E., \& Flanagan, K. (2008). Policies for science, technology and innovation: Translating rationales into regional policies in a multi-level setting. Research Policy, 37(5), 823-835. https://doi.org/10.1016/j.respol.2008.03.006

Lee, S. Y., Florida, R., \& Acs, Z. (2004). Creativity and entrepreneurship: A regional analysis of new firm formation. Regional Studies, 38(8), 879-891. https://doi.org/10.1080/0034340042000280910

Lei n. 12.527, de 18 de novembro de 2011. (2011). Regula o acesso a informações previsto no inciso XXXIII do art. 5, no inciso II do $\S 3^{\circ}$ do art. 37 e no $\S 2^{\circ}$ do art. 216 da Constituição Federal; altera a Lei no 8.112, de 11 de dezembro de 1990; revoga a Lei no 11.111, de 5 de maio de 2005, e dispositivos da Lei no 8.159, de 8 de janeiro de 1991; e dá outras providências. Retrieved from http://www.planalto.gov.br/ccivil_03/_ato2011. 2014/2011/lei/112527.htm

Leitner, A., Wehrmeyer, W., \& France, C. (2010). The impact of regulation and policy or radical eco-innovation: The need for a new understanding. Management Research Review, 33(11), 1022-1041. https://doi.org/10.1108/01409171011085877

Liu, F.-C., Simon, D. F., Sun, Y.-T., \& Cao, C. (2011). China’s innovation policies: Evolution, institutional structure, and trajectory. Research Policy, 40(7), 917-931. https://doi.org/10.1016/j.respol.2011.05.005

Lundström, A., \& Stevenson, L. (2005). Entrepreneurship policy: Theory and practice. New York, NY: Springer.

Mahapatra, R. (2017, October 25). Forget 2022, more than 110 million Indians would remain poor forever. Retrieved from https://www.downtoearth.org.in/news/governance/forget-the-target-of-2022-more-than-110-million-indianswould-remain-poor-forever-58934.

Marcotte, C. (2014). Entrepreneurship and innovation in emerging economies: Conceptual, methodological and contextual issues. International Journal of Entrepreneurial Behavior $\mathcal{E}$ Research, 20(1), $42-65$. https://doi.org/10.1108/ijebr-09-2012-0089

Martínez-Román, J. A., \& Romero, I. (2013). About the determinants of the degree of novelty in small businesses' product innovations. International Entrepreneurship $\mathcal{E}$ Management Journal, 9(4), 655-677. https://doi.org/10.1007/s11365-013-0269-0

Mazzarol, T., \& Reboud, S. (2011). Strategic innovation in small firms: An international analysis of innovation and strategic decision making in small to medium sized enterprises. Cheltenham, UK: Edward Elgar.

McCraw, T. K. (2007). Prophet of innovation: Joseph Schumpeter and creative destruction. Cambridge, MA: Belknap Press.

McGuirk, H., Lenihan, H., \& Hart, M. (2015). Measuring the impact of innovative human capital on small firms' propensity to innovate. Research Policy, 44(4), 965-976. https://doi.org/10.1016/j.respol.2014.11.008

Mehta, A. K., \& Shah, A. (2003). Chronic poverty in India: Incidence, causes and policies. World Development, 31(3), 491-511. https://doi.org/10.1016/s0305-750x(02)00212-7

Minniti, M. (2008). The role of government policy on entrepreneurial activity: Productive, unproductive, or destructive? Entrepreneurship Theory $\mathcal{E}$ Practice, 32(5), 779-790. https://doi.org/10.1111\%2Fj.15406520.2008.00255.x

Mirzanti, I. R., Simatupang, T. M., \& Larso, D. (2015). Mapping on entrepreneurship policy in Indonesia. ProcediaSocial E⿱ Behavioral Sciences, 169, 346-353. https://doi.org/10.1016/j.sbspro.2015.01.319

Mrożewski, M., \& Kratzer, J. (2017). Entrepreneurship and country-level innovation: Investigating the role of entrepreneurial opportunities. The Journal of Technology Transfer, 42(5), 1125-1142. https://doi.org/10.1007/s10961-016-9479-2

Öner, M. A., \& Kunday, Ö. (2016). A study on Schumpeterian and Kirznerian entrepreneurship in Turkey: 20062013. Technological Forecasting $\mathbb{E}$ Social Change, 102, 62-71. https://doi.org/10.1016/j.techfore.2015.09.005

OXFAM International. (n.d.). India: Extreme inequality in numbers. Retrieved from https://www.oxfam.org/en/evenit/india-extreme-inequality-numbers/

Pansera, M., \& Martinez, F. (2017). Innovation for development and poverty reduction: An integrative literature review. Journal of Management Development, 36(1), 2-13. https://doi.org/10.1108/jmd-02-2015-0013

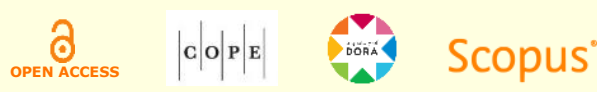


Parida, V., Oghazi, P., \& Cedergren, S. (2016). A study of how ICT capabilities can influence dynamic capabilities. Journal of Enterprise Information Management, 29(2), 179-201. https://doi.org/10.1108/jeim-07-2012-0039

Patanakul, P., \& Pinto, J. K. (2014). Examining the roles of government policy on innovation. The Journal of High Technology Management Research, 25(2), 97-107. https://doi.org/10.1016/j.hitech.2014.07.003

Petrakis, P. E., Kostis, P. C., \& Valsamis, D. G. (2015). Innovation and competitiveness: Culture as a long-term strategic instrument during the European Great Recession. Journal of Business Research, 68(7), 1436-1438. https://doi.org/10.1016/j.jbusres.2015.01.029

Plotnikova, M., Romero, I., \& Martínez-Román, J. A. (2016). Process innovation in small businesses: The selfemployed as entrepreneurs. Small Business Economics, 47(4), 939-954. https://doi.org/10.1007/s11187-016-9743-8

Qian, H., Acs, Z. J., \& Stough, R. R. (2013). Regional systems of entrepreneurship: The nexus of human capital, knowledge and new firm formation. Journal of Economic Geography, 13(4), 559-587. https://doi.org/10.1093/jeg/lbs009

Qian, H., \& Haynes, K. E. (2014). Beyond innovation: The small business innovation research program as entrepreneurship policy. The Journal of Technology Transfer, 39(4), 524-543. https://doi.org/10.1007/s10961-013. 9323-x

Ramos-Mejía, M., Franco-Garcia, M.-L., \& Jauregui-Becker, J. M. (2018). Sustainability transitions in the developing world: Challenges of socio-technical transformations unfolding in contexts of poverty. Environmental Science $\mathcal{E}$ Policy, 84, 217-223. https://doi.org/10.1016/j.envsci.2017.03.010

Reynolds, P. D., Storey, D. J., \& Westhead, P. (1994). Cross national comparisons of the variation in new firm formation rates. Regional Studies, 28(4), 443-456. https://doi.org/10.1080/00343409412331348306

Rodrigues, E. (2019). Seis Estados já declararam situação de calamidade financeira. O Estado de S.Paulo. Retrieved from https://economia.estadao.com.br/noticias/geral,seis-estados-ja-declararam-situacao-de-calamidadefinanceira, 70002683568 .

Romero, I., \& Martínez-Román, J. A. (2012). Self-employment and innovation. Exploring the determinants of innovative behavior in small businesses. Research Policy, 41(1), 178-189. https://doi.org/10.1016/j.respol.2011.07.005

Roper, S., Love, J. H., \& Bonner, K. (2017). Firms' knowledge search and local knowledge externalities in innovation performance. Research Policy, 46(1), 43-56. https://doi.org/10.1016/j.respol.2016.10.004

Rothwell, R. (1989). Small firms, innovation and industrial change. Small Business Economics, 1(1), 51-64. https://doi.org/10.1007/bf00389916

Sahut, J.-M., \& Peris-Ortiz, M. (2014). Small business, innovation, and entrepreneurship. Small Business Economics, 42(4), 663-668. https://doi.org/10.1007/s11187-013-9521-9

Santamaría, L., Nieto, M. J., \& Barge-Gil, A. (2009). Beyond formal R\&D: Taking advantage of other sources of innovation in low-and medium-technology industries. Research Policy, 38(3), 507-517. https://doi.org/10.1016/j.respol.2008.10.004

Saunders, M., Lewis, P., \& Thornill, A. (2009). Research methods for business students. Harlow, England: Pearson Education.

Schiller, D. (2006). Nascent innovation systems in developing countries: University responses to regional needs in Thailand. Industry $\mathcal{E}$ Innovation, 13(4), 481-504. https://doi.org/10.1080/13662710601032903

Schumpeter, J. A. (1939). Business cycles: A theoretical, historical and statistical analysis of the capitalist process. New York, NY: McGraw-Hill.

Sen, A. (2010). Desenvolvimento como liberdade. São Paulo, Brazil: Companhia das Letras.

Shane, S. (2012). Reflections on the 2010 AMR decade award: Delivering on the promise of entrepreneurship as a field of research. Academy of Management Review, 37(1), 10-20. https://doi.org/10.5465/amr.2011.0078

Silva, G., Dacorso, A. L. R., Costa, V. B., \& Di Serio, L. C. (2016). Relationships and partnerships in small companies: Strengthening the business through external agents. Brazilian Administration Review, 13(1), 1-18. https://doi.org/10.1590/1807-7692barnaahead0116

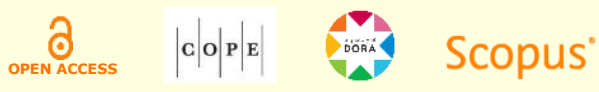


Silva, G., Dacorso, A. L. R., \& Montenegro, L. M. (2016). Mais do que negócios abertos, mentes abertas. Revista de Empreendedorismo e Gestão de Pequenas Empresas, 5(2), 2-23. https://doi.org/10.14211/regepe.v5i2.346

Squicciarini, M. (2017). Entrepreneurship, innovation and enterprise dynamics. Small Business Economics, $48(2), 273$. 278. https://doi.org/10.1007/s11187-016-9784-z

Stephens, H. M., Partridge, M. D., \& Faggian, A. (2013). Innovation, entrepreneurship and economic growth in lagging regions. Journal of Regional Science, 53(5), 778-812. https://doi.org/10.1111/jors.12019

Storey, D. J. (2014). Understanding the small business sector: Reflections and confessions. In P. Braunerhjelm (Ed.), 20 years of entrepreneurship research, Swedish entrepreneurship forum (Chap. 2, pp. 21-33). Stockholm, Sweden: Swedish Entrepreneurship Forum.

Thurik, A. R., Stam, E., \& Audretsch, D. B. (2013). The rise of the entrepreneurial economy and the future of dynamic capitalism. Technovation, 33(8-9), 302-310. https://doi.org/10.1016/j.technovation.2013.07.003

Tödtling, F., \& Trippl, M. (2005). One size fits all?: Towards a differentiated regional innovation policy approach. Research Policy, 34(8), 1203-1219. https://doi.org/10.1016/j.respol.2005.01.018

Tsuja, P. Y., \& Mariño, J. O. (2013). The influence of the environment on organizational innovation in service companies in Peru. Revista Brasileira de Gestão de Negócios, 15(49), $582-600$. https://doi.org/10.7819/rbgn.v15i49.1586

Van der Sluis, J., Van Praag, M., \& Vijverberg, W. (2008). Education and entrepreneurship selection and performance: A review of the empirical literature. Journal of Economic Surveys, 22(5), 795-841. https://doi.org/10.1111/j.1467-6419.2008.00550.x

Van Stel, A., Carree, M., \& Thurik, R. (2005). The effect of entrepreneurial activity on national economic growth. Small Business Economics, 24(3), 311-321. https://doi.org/10.1007/s11187-005-1996-6

Veugelers, R., \& Schweiger, H. (2016). Innovation policies in transition countries: One size fits all? Economic Change Eु Restructuring, 49(2-3), 241-267. https://doi.org/10.1007/s10644-015-9167-5

Von Tunzelmann, N., \& Acha, V. (2005). Innovation in "low-tech" industries. In J. Fagerberg, \& D. C. Mowery (Eds.), The Oxford handbook of innovation (Chapter 15, pp. 407-432). New York, NY: Oxford University Press.

World Economic Forum. (2018). The global competitiveness report 2018 - Brazil. Retrieved from http://reports.weforum.org/global-competitiveness-report-2018/country-economy-profiles/\#economy=BRA

Zaridis, A. D., \& Mousiolis, D. T. (2014). Entrepreneurship and SME's organizational structure. Elements of a successful business. Procedia - Social $\mathcal{E} \quad$ Behavioral Sciences, 148, 463-467. https://doi.org/10.1016/j.sbspro.2014.07.066

\section{Author contributions}

$1^{\text {st }}$ author: conceptualization (lead), formal analysis (lead), investigation (lead), methodology (lead), software (lead), writing-original draft (lead), writing-review and editing (equal).

$2^{\text {nd }}$ author: project administration (lead), supervision (lead), writing-review and editing (supporting).

$3^{\text {rd }}$ author: formal analysis (supporting), methodology (supporting), writing-original draft (supporting), writing-review and editing (equal). 


\section{Authors}

\section{Glessia Silva}

Universidade Federal de Sergipe, Departamento de Administração

Campus São Cristóvão, Cidade Univ. Prof. José Aloísio de Campos, Av. Marechal Rondon, s/n, 49100-000, São Cristóvão, SE, Brazil.

glessiasilva@hotmail.com

(iD) http://orcid.org/0000-0002-6044-512X

\section{Luiz Carlos Di Serio}

Fundação Getulio Vargas, Escola de Administração de Empresas de São Paulo

Av. Nove de Julho, 2029, Edifício John F. Kennedy, Bela Vista, 01313-902. São Paulo, SP, Brazil luiz.diserio@fgv.br

(iD) https://orcid.org/0000-0002-4592-0682

\section{Éder Danilo Bezerra}

Fundação Getulio Vargas, Escola de Administração de Empresas de São Paulo Av. Nove de Julho, 2029, Edifício John F. Kennedy, Bela Vista, 01313-902. São Paulo, SP, Brazil ederdanilo@live.com

(iD) https://orcid.org/0000-0002-2515-9769

Peer review is responsible for acknowledging an article's potential contribution to the frontiers of scholarly knowledge on business or public administration. The authors are the ultimate responsible for the consistency of the theoretical references, the accurate report of empirical data, the personal perspectives, and the use of copyrighted material. 